\title{
Effects of the hypoglycaemic drugs repaglinide and glibenclamide on ATP-sensitive potassium-channels and cytosolic calcium levels in $\beta$ TC3 cells and rat pancreatic beta cells
}

\author{
J. Gromada ${ }^{1,2}$, S. Dissing ${ }^{2}$, H. Kofod ${ }^{1}$, J.Frøkjar-Jensen ${ }^{1}$ \\ ${ }^{1}$ Diabetes Discovery, Novo Nordisk A/S, Bagsvaerd, Denmark \\ ${ }^{2}$ Department of Medical Physiology, The Panum Institute, University of Copenhagen, Copenhagen, Denmark
}

Summary The present study demonstrates the action of the hypoglycaemic drugs repaglinide and glibenclamide in cultured newborn rat islet cells and mouse $\beta$ TC 3 cells. In cell-attached membrane patches of newborn rat islet cells repaglinide $(10 \mathrm{nmol} /$ l) and glibenclamide $(20 \mathrm{nmol} / \mathrm{l})$ decrease the open probability of single ATP-sensitive $\mathrm{K}^{+}$-channels to approximately $10 \%$ of the activity prior to addition of the drugs in short-term experiments $(<5 \mathrm{~min})$. The influence of repaglinide and glibenclamide on the ATP-sensitive $\mathrm{K}^{+}$current was studied using the whole-cell patch clamp configuration. A half-maximal steady-state inhibition of the ATP-sensitive $\mathrm{K}^{+}$ currents is observed at $89 \mathrm{pmol} / \mathrm{l}$ repaglinide and at $47 \mathrm{pmol} / \mathrm{l}$ glibenclamide in whole-cell experiments of longer duration (30 min). Applying digital $\mathrm{Ca}^{2+}$ imaging on single $\beta \mathrm{TC} 3$ cells we found that repaglinide and glibenclamide induced a concentration-dependent increase in intracellular free $\mathrm{Ca}^{2+}$ concentration $\left(\left[\mathrm{Ca}^{2+}\right]_{\mathrm{i}}\right)$ with a half-maximal effect at $0.5 \mathrm{nmol} / 1$ for both drugs in long-term experiments $(30 \mathrm{~min}$ ). The rise in $\left[\mathrm{Ca}^{2+}\right]_{\mathrm{i}}$ results from $\mathrm{Ca}^{2+}$ entry through voltage-dependent $\mathrm{L}$-type $\mathrm{Ca}^{2+}$-channels since it is inhibited by verapamil $(10 \mu \mathrm{mol} / \mathrm{l})$. The effect of repaglinide and glibenclamide is partly reversible $(\approx 80 \%)$. [Diabetologia (1995) 38: 1025-1032]

Key words ATP-sensitive $\mathrm{K}^{+}$-channel, calcium, glibenclamide, non-insulin-dependent diabetes mellitus, repaglinide.
Sulphonylureas have been used in the treatment of patients with non-insulin dependent diabetes mellitus (NIDDM) for more than 30 years [1]. Sulphonylureas enhance insulin secretion from beta-cells by closure of $\mathrm{K}^{+}{ }_{\text {ATP-channels }}[2,3]$. This leads to a depolarization of the cell and subsequent activation of

Received: 18 November 1994 and in revised form: 21 March 1995

Corresponding author: Dr. J. Gromada, Islet Cell Physiology, Symbion Science Park, Novo Nordisk A/S, Fruebjergvej 3, DK-2100 Copenhagen, Denmark

Abbreviations: $\mathrm{K}^{+}$ATP-channel, ATP-sensitive potassium channel; $\left[\mathrm{Ca}^{2+}\right]_{i}$, intracellular free $\mathrm{Ca}^{2+}$ concentration; EGTA, ethylene glycol-O, $\mathrm{O}^{\prime}$-bis(2-aminoethyl]- $\mathrm{N}^{\prime}, \mathrm{N}, \mathrm{N}^{\prime}, \mathrm{N}^{\prime}$ tetraacetic acid; $\mathrm{IC}_{50}$, apparent inhibitor constant; repaglinide, ((S)-(+)-2-ethoxy-4-[2-((3-methyl-1-[2-(1-piperidinyl) phenyl]-butyl)amino)-2-oxoethyl) benzoic acid; NIDDM, non-insulin-dependent diabetes mellitus; $\beta$ TC3 cells, transgenic mouse insulinoma tumour cell line. voltage-dependent $\mathrm{Ca}^{2+}$-channels. $\mathrm{Ca}^{2+}$ then enters the cell and initiates insulin secretion [4]. Recently, it has become evident that sulphonylureas also promote insulin secretion by an interaction with the secretory machinery [5].

Sulphonylurea treatment can result in a gradual loss of glycaemic control with time, a phenomenon called secondary failure $[1,6]$. Furthermore, sulphonylurea treatment does not restore the first phase insulin secretion which is virtually absent in patients with NIDDM [7, 8]. In an attempt to circumvent these problems, and to improve blood glucose control, several new hypoglycaemic drugs have been developed. One such drug is repaglinide, a benzoic acid derivate (Fig. 1), which has been reported to enhance insulin secretion, to have a short plasma halflife and which is secreted predominantly via the bile [9]. Repaglinide has an insulinotropic effect in humans [9], although its mechanism of action in the pancreatic beta-cell remains to be established. There- 
<smiles>CCOc1cc(CC(=O)N[C@](C)(CC(C)C)c2ccccc2N2CCCCC2)ccc1C(=O)O</smiles>

Repaglinide<smiles>COc1ccc(Cl)cc1C(=O)NCCc1ccc(S(=O)(=O)NC(=O)NC2CCCCC2)cc1</smiles>

Glibenclamide

Fig.1. Structural formulae of repaglinide and glibenclamide

fore, we investigated the effects of repaglinide on cultured newborn rat islet cells and $\beta \mathrm{TC} 3$ cells using patch-clamp techniques and digital $\mathrm{Ca}^{2+}$ imaging. The results were compared with the sulphonylurea glibenclamide and partly presented previously [10].

\section{Materials and methods}

Chemicals. Fura-2 acetoxymethyl ester (Fura-2/AM) and fura-2 pentapotassium salt were supplied by Molecular Probes (Eugene, Ore. USA). EGTA was obtained from Fluka (Buchs, Switzerland). Repaglinide was synthesized at Dr. Karl Thomae GmbH (Biberach an der Riss, Germany). All other chemicals were obtained from Sigma Chemical (St. Louis, Mo., USA).

Cell culture. Islet cells were isolated from newborn rats and cultured for up to 3 months, as described previously [11]. The newborn rat islet cells were used for the electrophysiological recordings whereas the $\beta \mathrm{TC} 3$ cell line, derived from a transgenic mouse insulinoma [12], was used for all $\mathrm{Ca}^{2+}$ measurements. The latter cell line was used because we were unable to make the newborn rat cells attach to glass coverslips, necessary for measurements of $\left[\mathrm{Ca}^{2+}\right]_{\mathrm{i}}$. The $\beta \mathrm{TC} 3$ cells were cultured at $37^{\circ} \mathrm{C}$ in Dulbecco's modified Eagle medium containing $1000 \mathrm{mg} / \mathrm{l} \mathrm{D}$-glucose, $10 \%$ heat-inactivated fetal calf serum, penicillin $(50 \mathrm{U} / \mathrm{ml})$, streptomycin $(0.05 \mathrm{mg} / \mathrm{ml}), 2 \mathrm{mmol} / 1$ L-glutamine (Gibco, Roskilde, Denmark) and incubated in humidified $5 \% \mathrm{CO}_{2}$ in $95 \%$ air. Cells were passaged once each week and media were changed twice a week. All experiments were performed with cells from passage $30-45$.

Measurements of electrical activity. Single-channel and wholecell ion currents were recorded using an EPC-9 patch-clamp amplifier (Heka Elektronik, GmbH, Lambrecht, Germany), stored on video tape (JVC D860EH) via an analogue-to-digital converter (10B, Instructech Corporation, Elmont, N.Y., USA) and a low bandpass filter $(500 \mathrm{~Hz})$ to a chart recorder (DASH IV, Astro Med, West Warwick, R.I., USA). Pipettes were pulled from borosilicate glass (Modulohm A/S, Herlev, Denmark) on a vertical puller (BB-CH-PC Mecanex, Bromma, Switzerland), coated with Sylgard and heat polished at the tip. Pipette resistances ranged between 2 and $4 \mathrm{M} \Omega$ when filled with the pipette solution.

For cell-attached patch-clamp experiments the pipette solution contained (in mmol/1): $6 \mathrm{Na}^{+}, 155 \mathrm{~K}^{+}, 2 \mathrm{Ca}^{2+}, 1$ $\mathrm{Mg}^{2+}, 137 \mathrm{Cl}^{-}, 10$ EGTA, 0.3 ATP, 5 HEPES, pH 7.2: the extracellular solution contained (in mmol/l): $140 \mathrm{Na}^{+}, 4 \mathrm{~K}^{+}, 2$ $\mathrm{Ca}^{2+}, 1 \mathrm{Mg}^{2+}, 150 \mathrm{Cl}^{-}, 10 \mathrm{HEPES}, \mathrm{pH}$ 7.3. In cell-attached single-channel experiments the recordings were performed at the resting membrane potential of the cell and the applied voltage was $0 \mathrm{mV}$. In whole-cell experiments the same solutions were used as described above. The membrane potential was held at $-70 \mathrm{mV}$ and hyper- and depolarizing voltage pulses of $10 \mathrm{mV}$ amplitude and $250 \mathrm{~ms}$ duration were applied alternately every $1.5 \mathrm{~s}$ [13]. At the applied membrane potentials, voltage dependent currents, i.e., the $\mathrm{Ca}^{2+}$ inward currents and the delayed $\mathrm{K}^{+}$outward current are not induced and therefore most of

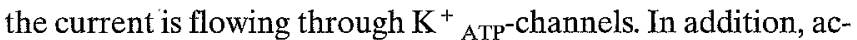
tivation of $\mathrm{Ca}^{2+}$-dependent $\mathrm{K}^{+}$-channels was prevented by including EGTA in the pipette solution $[14,15]$. Solutions were applied by gravity feed from a series of parallel pipes. Solution changes around the cell were complete within $5 \mathrm{~s}$ as measured by monitoring the membrane potential during a step in extracellular $\mathrm{K}^{+}$concentration from 4 to $45 \mathrm{mmol} / \mathrm{l}$. The experiments were performed at room temperature.

Measurements of $\left[\mathrm{Ca}^{2+}\right]_{\mathrm{i}}$. Images of $\left[\mathrm{Ca}^{2+}\right]_{\mathrm{i}}$ in single $\beta \mathrm{TC} 3$ cells were obtained by means of a fluorescence microscope (Zeiss Axiovert 135, Oberkochen, Germany) with a Xenon lamp (75 W), a CCD camera (Dage-MTI, Michigan City, Ind., USA) with an intensifier (Genesis, Dage-MTI) and a digital image processing system (Universal imaging, West Chester, $\mathrm{Pa}$., USA). The cells were loaded with $3 \mu \mathrm{mol} / 1$ fura-2/AM for $40 \mathrm{~min}$ at $37^{\circ} \mathrm{C}$. Before the experiment the cells were washed twice with extracellular solution (see previous section) and placed in a perfusion chamber which allows for a continuous flow of control or test solution at rates between $0.1-2 \mathrm{ml} / \mathrm{min}$. Images were obtained by an oil-immersion UV permeable objective (Zeiss Achrostigmat $40 \times, 1.30$ numerical aperture) and transferred to a video tape recorder (Umatic SP, VO 9600 , Sony, Copenhagen, Denmark). The images were obtained by averaging eight frames using a sample rate between $0.2-0.5 \mathrm{~Hz}$. The data were obtained by averaging the pixel grey values inside a $4 \times 4-\mu \mathrm{m}$ window placed in the centre of the cells.

The free intracellular $\mathrm{Ca}^{2+}$ concentrations were calculated from the measurements of the ratio of fluorescence intensities according to the equation [16]: $\left[\mathrm{Ca}^{2+}\right]_{\mathrm{i}}=\mathrm{K}_{\mathrm{d}} \cdot\left[\left(\mathrm{R}-\mathrm{R}_{\min }\right) /\right.$ $\left.\left(\mathrm{R}_{\max }-\mathrm{R}\right)\right] \cdot\left(\mathrm{S}_{\mathrm{f} 2} / \mathrm{S}_{\mathrm{b} 2}\right)$. Calibrations of intracellular fura- 2 signals were done by adding ionomycin to a final concentration of $1 \mu \mathrm{mol} / 1$ in order to equilibrate $\mathrm{Ca}^{2+}$ across the plasma membrane. The grey values obtained for $R_{\max }$ amounted in average to 241 . $R_{\min }$ and the proportionality constant $\left(\mathrm{S}_{\mathrm{f} 2} / \mathrm{S}_{\mathrm{b} 2}\right)$ were obtained from a high $\mathrm{K}^{+}$-medium with fura-2 pentapotassium salt and $10 \mathrm{mmol} / 1$ EGTA and amounted to 27 and 9.8, respectively. A value for the apparent dissociation constant $\left(\mathrm{K}_{\mathrm{d}}\right)$ for $\mathrm{Ca}^{2+}$ binding to fura- 2 of $224 \mathrm{nmol} / 1$ was used [16]. All experiments were performed at room temperature $\left(20-22^{\circ} \mathrm{C}\right)$. 


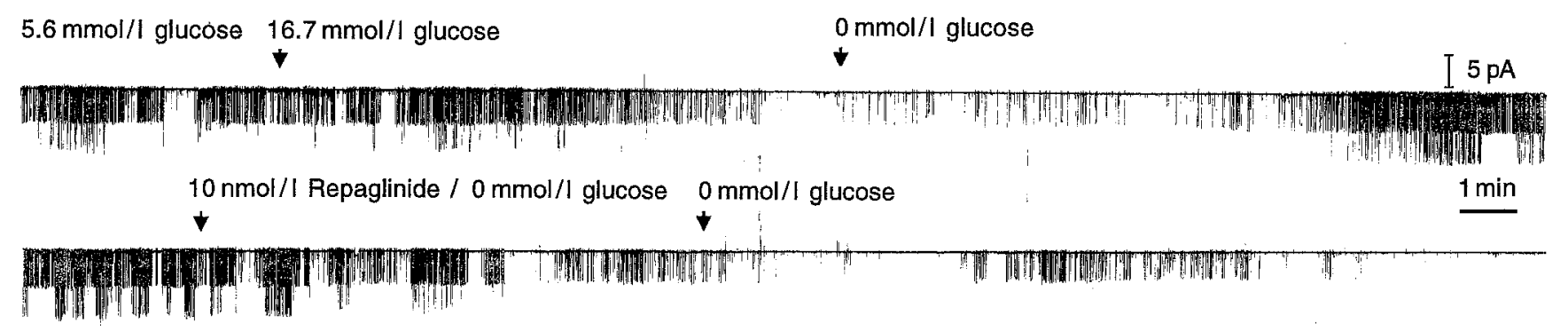

Fig. 2. Effect of glucose and repaglinide on $\mathrm{K}^{+}{ }_{A T P}$-channels in a cell-attached patch of cultured beta-cell from neonatal rats. Continuous tracing depicting closure of $\mathrm{K}^{+}{ }_{\mathrm{ATP}}$-channels induced by $16.8 \mathrm{mmol} / 1$ glucose and $10 \mathrm{nmol} / 1 \mathrm{repaglinide.} \mathrm{The}$ recording was performed at the resting membrane potential of the cell and the applied voltage was $0 \mathrm{mV}$ with extracellular solution in the bath and intracellular solution in the pipette.

\section{Statistical analysis}

All data are expressed as means \pm SEM for $n$ tested cells. Curves were fitted to the data by a non-linear least-squares method using the computer program Statgraphics from STST Inc. (Rockville, Md., USA). In order to measure the inhibitory effect of repaglinide and glibenclamide on the mean current amplitude a curve was fitted to the data points by the following equation, which is a simplified version of the Hill equation assuming a cooperativity of one:

$\mathrm{I} / \mathrm{I}_{\mathrm{c}}=\left[\mathrm{IC}_{50}\right] /\left(\left[\mathrm{IC}_{50}\right]+[\mathrm{S}]\right)$

where $I$ is the change in current amplitude, $I_{c}$ is the maximum change in current amplitude in the absence of drug, $\left[\mathrm{IC}_{50}\right]$ is concentration of repaglinide or glibenclamide giving half-maximal inhibition and $S$ is the concentration of the inhibitor. In these experiments differences in cell size were not corrected for, as we did not find any correlation between cell size and the maximum current amplitudes.

For measurements of concentration-response curves the data were fitted by means of the Michaelis-Menten equation:

$\Delta\left[\mathrm{Ca}^{2+}\right]_{\mathrm{i}}=\Delta\left(\left[\mathrm{Ca}^{2+}\right]_{\mathrm{i}}\right) \max \cdot[\mathrm{S}] /\left(\mathrm{k}_{\mathrm{s}}+[\mathrm{S}]\right)$

where $\Delta\left[\mathrm{Ca}^{2+}\right]_{\mathrm{i}}$ is the change in $\left[\mathrm{Ca}^{2+}\right]_{\mathrm{i}}, \Delta\left(\left[\mathrm{Ca}^{2+}\right]_{\mathrm{i}}\right)_{\max }$ is the maximal rise observed in $\left[\mathrm{Ca}^{2+}\right]_{\mathrm{i}}, \mathrm{S}$ is the concentration of drug and $\mathrm{k}_{\mathrm{s}}$ is the drug concentration causing a half-maximal rise in $\left[\mathrm{Ca}^{2+}\right]_{i}$.

\section{Results}

Effects of glucose and repaglinide on $K^{++}{ }_{\text {ATP-channel }}$ activity. Figure 2 shows the effect of glucose and repaglinide on individual $\mathrm{K}^{+}{ }_{\text {ATP-channels in a cell-at- }}$ tached patch of membrane of cultured beta-cells from neonatal rats. From observations of channel activity over a range of voltages we found a reversal potential of -70 to $-80 \mathrm{mV}$ and a maximum slope conductance of approximately $70 \mathrm{pS}$ in symmetrical $\mathrm{K}^{+}$ solutions. In most experiments, glucose alone $(16.7 \mathrm{mmol} / \mathrm{l})$ totally blocked the $\mathrm{K}^{+} \mathrm{ATP}^{\text {-channels }}$ within approx. $8 \mathrm{~min}$. This effect is reversible since reducing bath glucose to $0 \mathrm{mmol} / \mathrm{l}$ results in the return
The currents are displayed as downward deflections indicating that the currents are inward. This is solely due to the high $\mathrm{K}^{+}$ concentration of the intracellular solution in the pipette and under physiological conditions the currents will be outwardly directed tending to repolarize the beta-cell. The experiment is performed at $22-24^{\circ} \mathrm{C}$

of channel activity within 5-10 min. Subsequent addition of repaglinide $(10 \mathrm{nmol} / \mathrm{l})$ inhibited channel activity approximately $90 \%$ within $1-4 \mathrm{~min}$. The effect of repaglinide was not reversible within $30 \mathrm{~min}$ of washout. Similar results were obtained with glibenclamide, although $20 \mathrm{nmol} / 1$ was required in order to obtain $90 \%$ inhibition of channel activity. The effects of repaglinide and glibenclamide are specific for $\mathrm{K}^{+}{ }_{\mathrm{ATP}}$-channels, since the drugs did not affect the $\mathrm{Ca}^{2+}$-sensitive $\mathrm{K}^{+}$-channels or the smaller $(\approx 15$ pS) $\mathrm{K}^{+}$-channels also present in the beta-cells (data not shown). All experiments examining the effects of repaglinide or glibenclamide were performed in a glucose-free medium in order to avoid contributions from glucose induced changes on $\mathrm{K}^{+}{ }_{\mathrm{ATP}}$-channel activity and $\left[\mathrm{Ca}^{2+}\right]_{i}$.

Effect of repaglinide and glibenclamide on ATP-sensitive $K^{+}$whole-cell current. At low repaglinide and glibenclamide concentrations it becomes difficult to separate drug effect from spontaneous rundown of $\mathrm{K}^{+}{ }_{\mathrm{ATP}}$-channels. Thus, in order to establish the doseresponse relationship for repaglinide and glibenclamide we used a different whole-cell protocol [13]. The beta-cells were preincubated for $30 \mathrm{~min}$ with different concentrations of the drugs and the current was recorded at a holding potential of $-70 \mathrm{mV}$ applying hyper- and depolarizing pulses of $10 \mathrm{mV}$. Figure $3 \mathrm{~A}$ illustrates the current responses in the absence of drugs and in the presence of $1 \mathrm{nmol} / \mathrm{l}$ repaglinide. After patch rupture and dialysis of the cell with a pipette solution of low ATP concentration $(0.3 \mathrm{mmol} / \mathrm{l})$ the whole-cell $\mathrm{K}^{+}$current gradually increased to a maximal value of approximately $500 \mathrm{pA}$ in the control and approximately $50 \mathrm{pA}$ in the presence of 1 $\mathrm{nmol} / \mathrm{l}$ repaglinide. We found that an equilibrium state of the blocking effect of all tested drug concentrations was achieved after $30 \mathrm{~min}$ of incubation. Exposure of the cells to different repaglinide and glibenclamide concentrations caused a concentration-dependent decrease of the maximal current amplitude. 
A
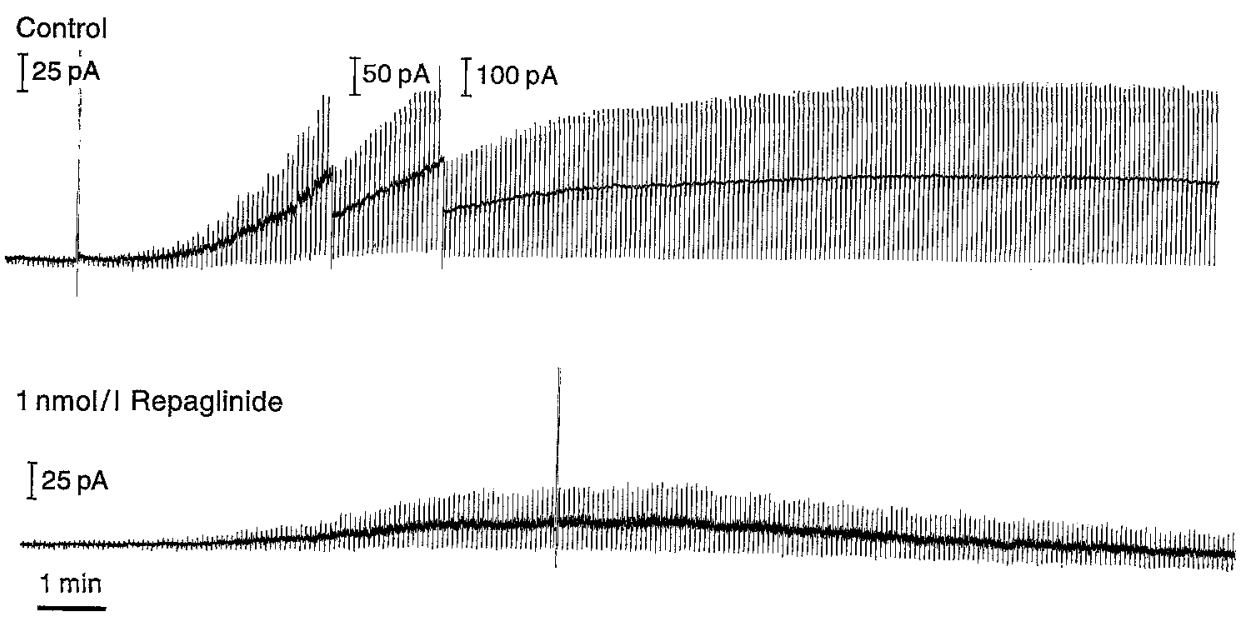

B
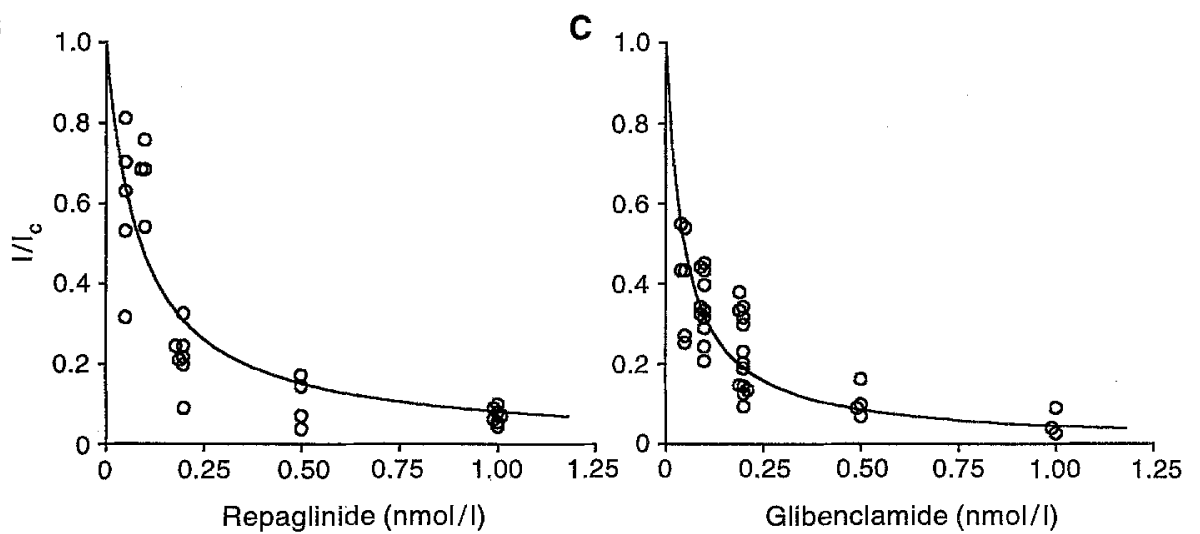

Fig.3. A Effect of repaglinideon ATP-sensitive $\mathrm{K}^{+}$whole-cell currents. Newborn rat beta-cells were incubated for $30 \mathrm{~min}$ without or with repaglinide. Membrane currents were then measured with pipettes containing intracellular solution with $0.3 \mathrm{mmol} / \mathrm{l}$ ATP. Due to wash-out of ATP from the cytoplasm the current amplitude increased during the first minutes after patch rupture. Note the change in scale of the current amplitude in control. The current amplitude was determined after reaching a maximum. $\mathbf{B}, \mathbf{C}$ Concentration dependence of inhibition of current responses for repaglinide and glibenclamide. The ordinate shows the fraction of the maximum currents in the presence and absence of inhibitor. Curves were fitted as described in Materials and methods
By fitting a curve to the data (Eq. I) an $\mathrm{IC}_{50}$-value of $89 \pm 13 \mathrm{pmol} / \mathrm{l}$ for repaglinide and $47 \pm 4 \mathrm{pmol} / \mathrm{l}$ for glibenclamide was calculated (Fig. 3B,C).

Effects of repaglinide and glibenclamide on $\left[\mathrm{Ca}^{2+}\right]_{\mathrm{i}}$. Figure 4 shows typical time courses of the rise in $\left[\mathrm{Ca}^{2+}\right]_{\mathrm{i}}$ induced by maximally stimulating concentrations of repaglinide and glibenclamide $(100 \mathrm{nmol} / \mathrm{l})$ in $\beta \mathrm{TC} 3$ cells. The resting $\left[\mathrm{Ca}^{2+}\right]_{\mathrm{i}}$ in unstimulated $\beta$ TC3 cells amounted to $189 \pm 7 \mathrm{nmol} / 1(n=59)$. The $\mathrm{Ca}^{2+}$ responses were sustained and $800-900 \mathrm{nmol} / 1$ in amplitude and had a latency of 30-60 s. In the absence of extracellular $\mathrm{Ca}^{2+}$ (with $100 \mu \mathrm{mol} / \mathrm{l}$ EGTA) addition of repaglinide did not evoke any increase in $\left[\mathrm{Ca}^{2+}\right]_{\mathrm{i}}$ but subsequent change to a $\mathrm{Ca}^{2+}$-containing medium caused an immediate increase in $\left[\mathrm{Ca}^{2+}\right]_{\mathrm{i}}$ (Fig. 4C). Furthermore, the $\left[\mathrm{Ca}^{2+}\right]_{\mathrm{i}}$ response to 100 nmol/l repaglinide was completely inhibited by the addition of $10 \mu \mathrm{mol} / \mathrm{l}$ verapamil, a L-type $\mathrm{Ca}^{2+}$-channel blocker (Fig. 4D).

By exposing $\beta$ TC3 cells to different repaglinide and glibenclamide concentrations, we found that the time course of change in $\left[\mathrm{Ca}^{2+}\right]_{i}$ strongly depended on the applied drug concentration. Low drug concentrations caused a very gradual increase in $\left[\mathrm{Ca}^{2+}\right]_{i}$ reaching peak values after $20-30 \mathrm{~min}$, whereas high- er concentrations caused a faster increase in $\left[\mathrm{Ca}^{2+}\right]$ i (Fig. 5A, B). No such long-term change in $\left[\mathrm{Ca}^{2+}\right]_{\mathrm{i}}$ were observed in the absence of drug. Figure $5 \mathrm{C}, \mathrm{D}$ shows concentration-response curves for the repaglinide- and glibenclamide-induced changes in $\left[\mathrm{Ca}^{2+}\right]_{\mathrm{i}}$ when measured at $30 \mathrm{~min}$, where $\left[\mathrm{Ca}^{2+}\right]_{\mathrm{i}}$ had reached a maximum level at all tested drug concentrations. When $\left[\mathrm{Ca}^{2+}\right]_{\mathrm{i}}$ was induced to rise with repaglinide (Fig. 5C) the $\Delta\left(\left[\mathrm{Ca}^{2+}\right]_{\mathrm{i}}\right)_{\max }$ amounted to $731 \pm 15 \mathrm{nmol} / 1$ with a half-maximal effective concentration of $0.53 \pm 0.04 \mathrm{nmol} / \mathrm{l}$. In the presence of glibenclamide (Fig. 5D) the $\Delta\left(\left[\mathrm{Ca}^{2+}\right]_{\mathrm{i}}\right)_{\mathrm{max}}$ amounted to $715 \pm 15 \mathrm{nmol} / \mathrm{l}$ and $\mathrm{k}_{\mathrm{s}}$ to $0.52 \pm 0.04 \mathrm{nmol} / \mathrm{l}$.

Reversibility of repaglinide and glibenclamide. We have investigated the reversibility of repaglinide and glibenclamide on the ATP-sensitive whole-cell $\mathrm{K}^{+}$current in newborn rat islet cells. After pretreatment with $100 \mathrm{nmol} / \mathrm{l}$ of each drug for $30 \mathrm{~min}$ the cells were washed with drug free medium for variable periods of time before a whole cell experiment was performed. After $250 \mathrm{~min}$ of washing we found approximately $80 \%$ recovery of the maximal ATP-sensitive $\mathrm{K}^{+}$current in cells pretreated with $100 \mathrm{nmol} / \mathrm{l}$ repaglinide (Fig. 6A). Similar results were obtained with glibenclamide (data not shown). We have also exam- 
A
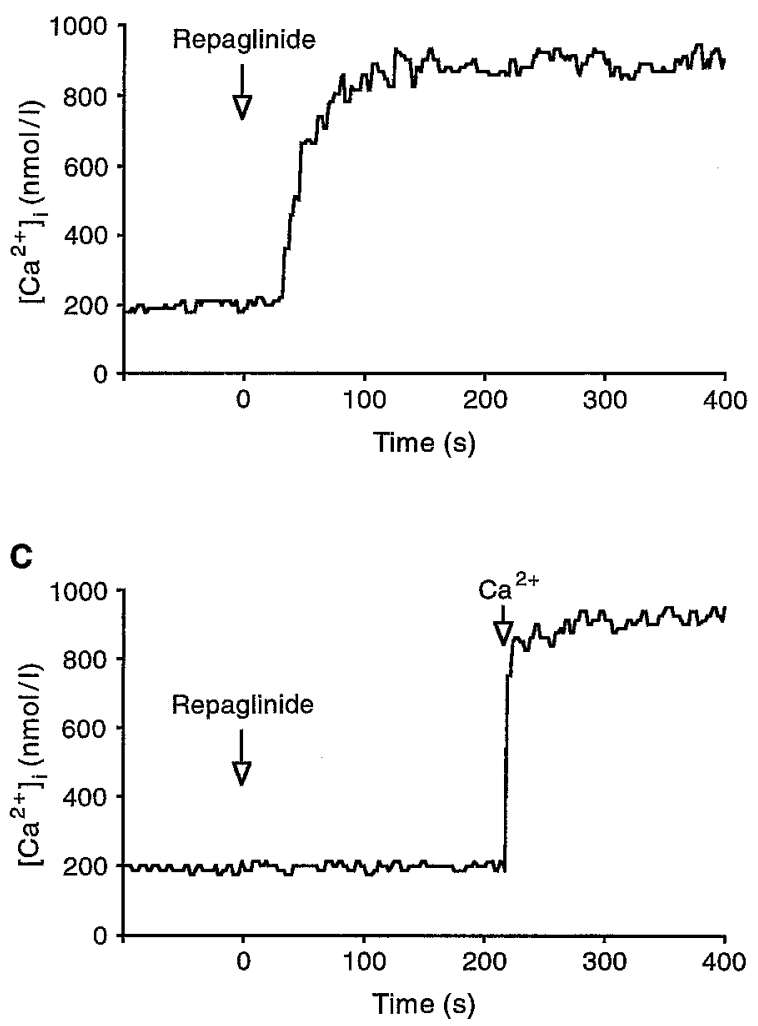

Fig.4. A, B Time course of changes in $\left[\mathrm{Ca}^{2+}\right]_{\mathrm{i}}$ in $\beta \mathrm{TC} 3$ cells following stimulation with repaglinide or glibenclamide $(100$ $\mathrm{nmol} / \mathrm{l})$. C Inhibition of repaglinide induced changes in $\left[\mathrm{Ca}^{2+}\right]_{\mathrm{i}}$ when added to a medium without $\mathrm{Ca}^{2+}$ and with $100 \mu \mathrm{mol} / \mathrm{l}$ EGTA. Subsequent perfusion with a $\mathrm{Ca}^{2+}$-containing medium induced an increase in $\left[\mathrm{Ca}^{2+}\right]_{\mathrm{i}}$. $\mathbf{D}$ Inhibition of repaglinide $(100 \mathrm{nmol} / \mathrm{l})$ evoked $\left[\mathrm{Ca}^{2+}\right]_{\mathrm{i}}$ response by $10 \mu \mathrm{mol} / \mathrm{I}$ verapamil when added as indicated by the arrow. The tracing is representative of $18-43$ experiments

ined the reversibility of repaglinide and glibenclamide on $\left[\mathrm{Ca}^{2+}\right]_{i}$ by including a washing step after the cells had reached their maximal $\left[\mathrm{Ca}^{2+}\right]_{i}$ in response to drug application $(100 \mathrm{nmol} / \mathrm{l})$. In the $\mathrm{Ca}^{2+}$ experiments inclusion of albumin $(10 \mathrm{mg} / \mathrm{ml})$ in the washing solution enhanced the back regulation of $\left[\mathrm{Ca}^{2+}\right]_{\mathrm{i}}$. It is evident from Fig. $6 \mathrm{~B}$ that $\left[\mathrm{Ca}^{2+}\right]_{\mathrm{i}}$ was decreased to near resting levels within $30 \mathrm{~min}$ of washing in a cell stimulated with repaglinide $(100 \mathrm{nmol} / 1)$. At this time $\left[\mathrm{Ca}^{2+}\right]_{\mathrm{i}}$ was reduced to $265 \pm 32 \mathrm{nmol} / 1$ for repaglinide and to $274 \pm 44 \mathrm{nmol} / \mathrm{l}$ for glibenclamide $(n=9)$. Subsequent exposure of the same cells to repaglinide or glibenclamide $(100 \mathrm{nmol} / \mathrm{l})$ induced a new increase in $\left[\mathrm{Ca}^{2++}\right]_{\mathrm{i}}$ reaching $623 \pm 37 \mathrm{nmol} / 1$ for repaglinide and $637 \pm 46$ for glibenclamide.
B
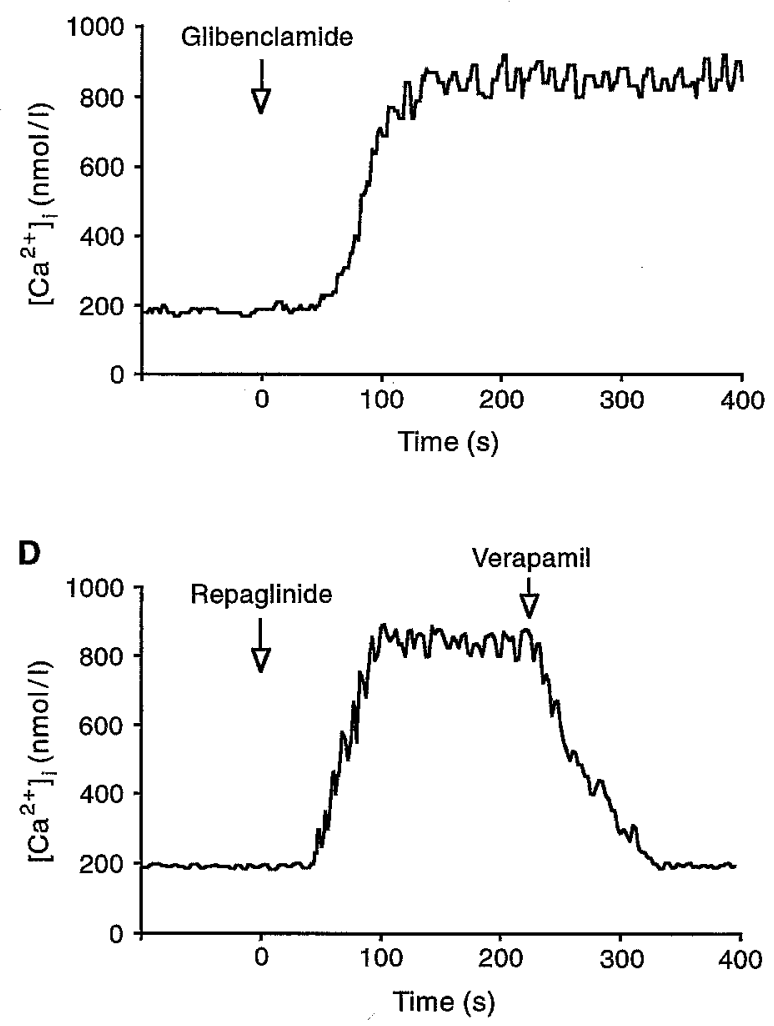

Discussion

The present study demonstrates that the hypoglycaemic drugs repaglinied and glibenclamide block the $\mathrm{K}^{+} \mathrm{ATP}^{-c h a n n e l s ~ f o u n d ~ i n ~ p a n c r e a t i c ~ b e t a-c e l l s, ~ t h e r e-~}$ by causing $\mathrm{Ca}^{2+}$ influx through voltage-dependent $\mathrm{L}$ type $\mathrm{Ca}^{2+}$-channels and a subsequent increase in $\left[\mathrm{Ca}^{2+}\right]_{\mathrm{i}}$. The $\mathrm{K}^{+}{ }_{\mathrm{ATP}}{ }^{- \text {channels found in the present }}$ study are similar to those previously described in beta-cells from newborn rats [17] and in other types of beta-cells [4, 18]. Repaglinide and glibenclamide caused a dose-dependent inhibition of the $\mathrm{K}^{+}{ }_{\mathrm{ATP}^{-}}$ channels, which constitute the resting conductance of the beta-cell $[4,18]$. Thus, $89 \mathrm{pmol} / 1$ repaglinide blocked the ATP-sensitive $\mathrm{K}^{+}$-currents half-maximally whereas glibenclamide inhibited the currents half-maximally at $47 \mathrm{pmol} / \mathrm{l}$. By comparison, Sturgess et al. [19] found that $27 \mathrm{nmol} / \mathrm{l}$ glibenclamide was needed in order to block the ATP-sensitive $\mathrm{K}^{+}$current in CRI-G1 insulinoma cells half-maximally. In mouse pancreatic $\beta$-cells $0.4-0.6 \mathrm{nmol} / 1$ glibenclamide (free concentrations) was required in order to inhibit the ATP-sensitive $\mathrm{K}^{+}$-current half-maximally $[20,21]$. However, in RIN cells $60 \mathrm{pmol} / 1$ glibenclamide was half-maximally effective on ${ }^{86} \mathrm{Rb}^{+}$efflux which reflects the activity of the $\mathrm{K}^{+}{ }_{\text {ATP-channels }}$ [22].

We have shown the presence of functional $\mathrm{K}^{+} \mathrm{ATP}^{-}$ channels in $\beta \mathrm{TC} 3$ cells which were sensitive to inhibition by repaglinide and glibenclamide (data not shown). Thus, the observed rise in $\left[\mathrm{Ca}^{2+}\right]_{i}$ in re- 
1030

\section{A}
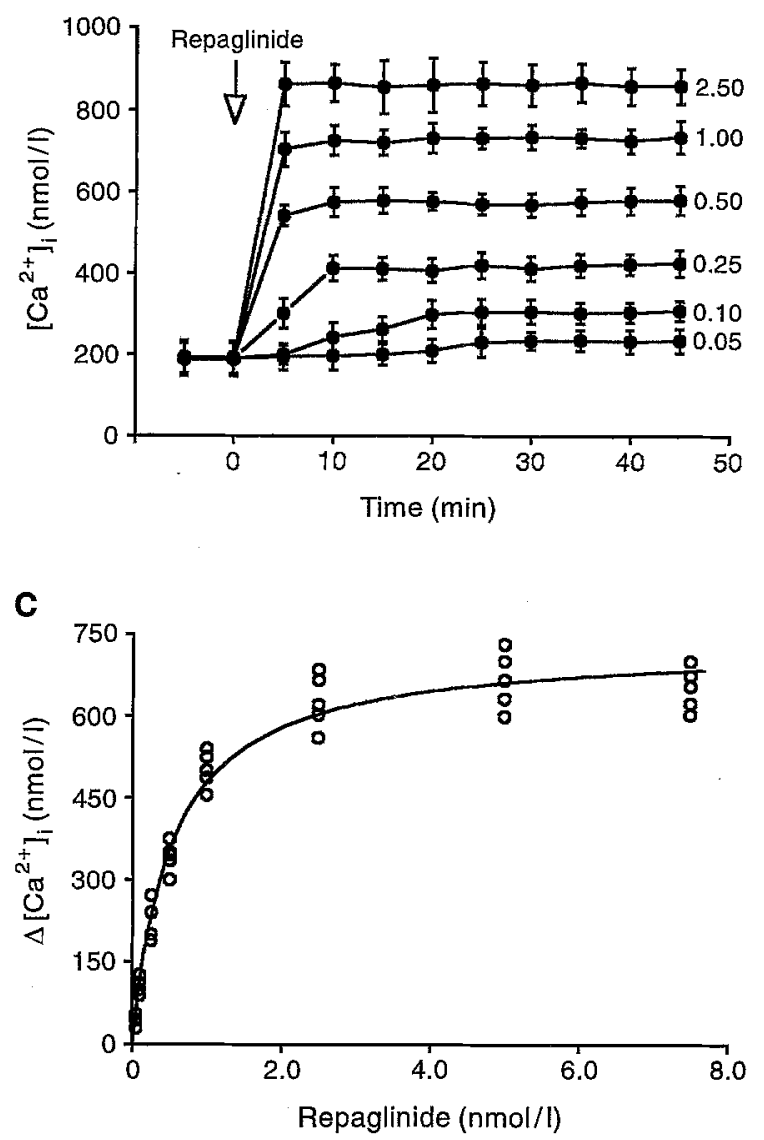

Fig. 5 (A-D). Time and concentration-dependent effects of repaglinide and glibenclamide on $\left[\mathrm{Ca}^{2+}\right]_{i}$ in $\beta \mathrm{TC} 3$ cells. $\mathbf{A}, \mathbf{B}$ Time-dependent changes in $\left[\mathrm{Ca}^{2+}\right]_{i}$ after stimulation with repaglinide and glibenclamide (concentrations are shown on the right of the graphs in nanomol/l). C, D Concentration-response curves for the repaglinide- and glibenclamide-induced changes in $\left[\mathrm{Ca}^{2+}\right]_{i}$. The ordinate shows the changes in $\left[\mathrm{Ca}^{2+}\right]_{i}$ $\left(\Delta\left[\mathrm{Ca}^{2+}\right]_{i}\right)$ obtained by subtracting the unstimulated $\left[\mathrm{Ca}^{2+}\right]_{\mathrm{i}}$ from that measured at $\min 30$. Curves were fitted as described in Materials and methods

sponse to repaglinide or glibenclamide is due to inhibition of the $\mathrm{K}^{+}{ }_{\mathrm{ATP}}$-channels, thereby causing membrane depolarization and $\mathrm{Ca}^{2+}$ influx. The extracellular source of $\mathrm{Ca}^{2+}$ is supported by the observation that verapamil, a L-type $\mathrm{Ca}^{2+}$ channel blocker, prevents the rise in $\left[\mathrm{Ca}^{2+}\right]_{i}$.

Repaglinide and glibenclamide were about six and tenfold more potent in the electrophysiological experiments than in measurements of $\left[\mathrm{Ca}^{2+}\right]_{\mathrm{i}}\left(\mathrm{k}_{\mathrm{s}} \approx 0.5\right.$ nmol/1 for both drugs). Patch-clamp experiments have revealed that complete closure of the $\mathrm{K}^{+} \mathrm{ATP}^{-}$ channels is required for the pancreatic beta-cell to be depolarized beyond the threshold for the generation of $\mathrm{Ca}^{2+}$-dependent action potentials [4]. Against this background it is clear that higher concentrations of repaglinide and glibenclamide are nee-
J. Gromada et al:: Effect of repaglinide and glibenclamide on $\beta$ cells

B
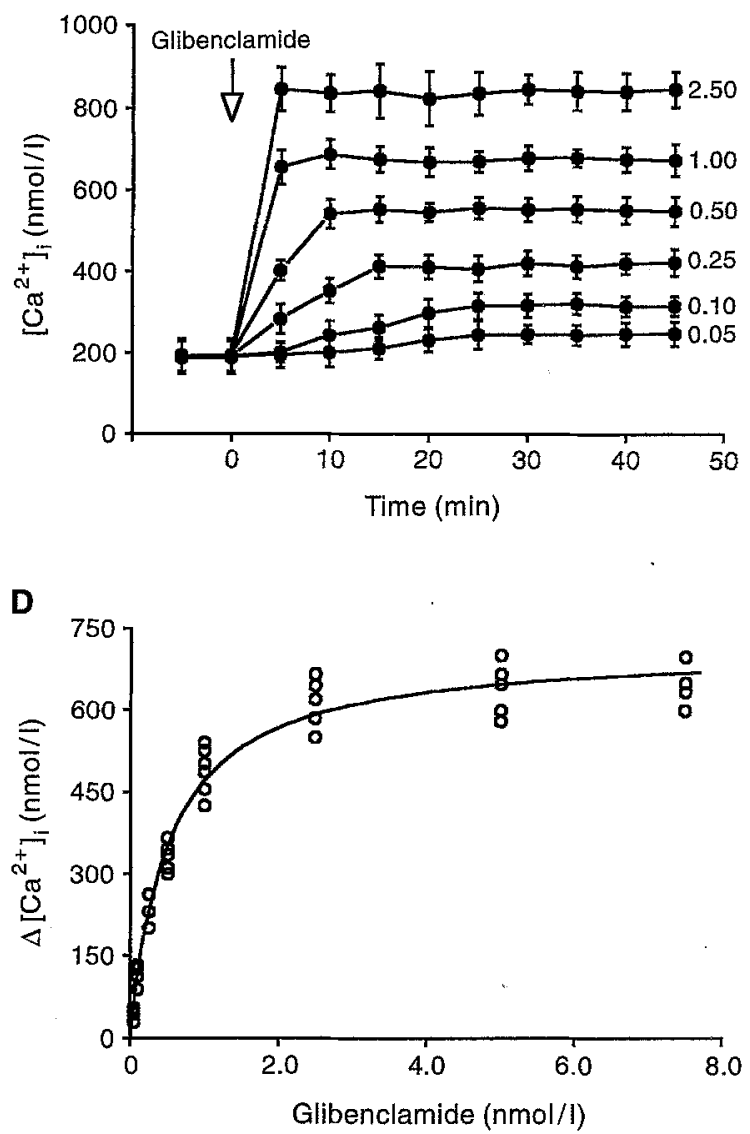

ded to cause a half-maximal increase in $\left[\mathrm{Ca}^{2+}\right]_{\mathrm{i}}$. However, we acknowledge that the dose-response re-

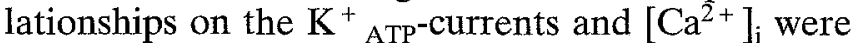
determined on two different beta-cell types. Preliminary results on $\beta \mathrm{TC} 3$ cells have shown that the concentrations of repaglinide and glibenclamide causing half-maximal inhibition of the ATP-sensitive $\mathrm{K}^{+}$whole-cell current were approximately 100 $\mathrm{pmol} / 1$ which is nearly identical with those obtained in the present study on newborn rat islet cells. Thus, the difference in the dose-response relationships for repaglinide and glibenclamide determined in the present study is likely to reflect true differences in potency and is probably not due to the different cell types used. Our data on the potency of repaglinide and glibenclamide to cause an increase in $\left[\mathrm{Ca}^{2+}\right]_{\mathrm{i}} \mathrm{com}-$ pare favourably with the potency of glibenclamide to stimulate insulin release in mouse pancreatic islets $\left(\mathrm{EC}_{50} \approx 0.5 \mathrm{nmol} / \mathrm{l}\right)[21]$.

Recently, it was demonstrated that the undissociated forms of glibenclamide and related compounds are the active forms for inhibition of the ATP-sensitive $\mathrm{K}^{+}$-currents and that the drugs probably gain access to their binding sites from the lipid phase of the beta-cell membrane [23]. In addition, an internalization of glibenclamide in rat islet cells occurs to a rather large extent where it preferentially associates with insulin secretory granules [24]. Thus, the rate of 
A
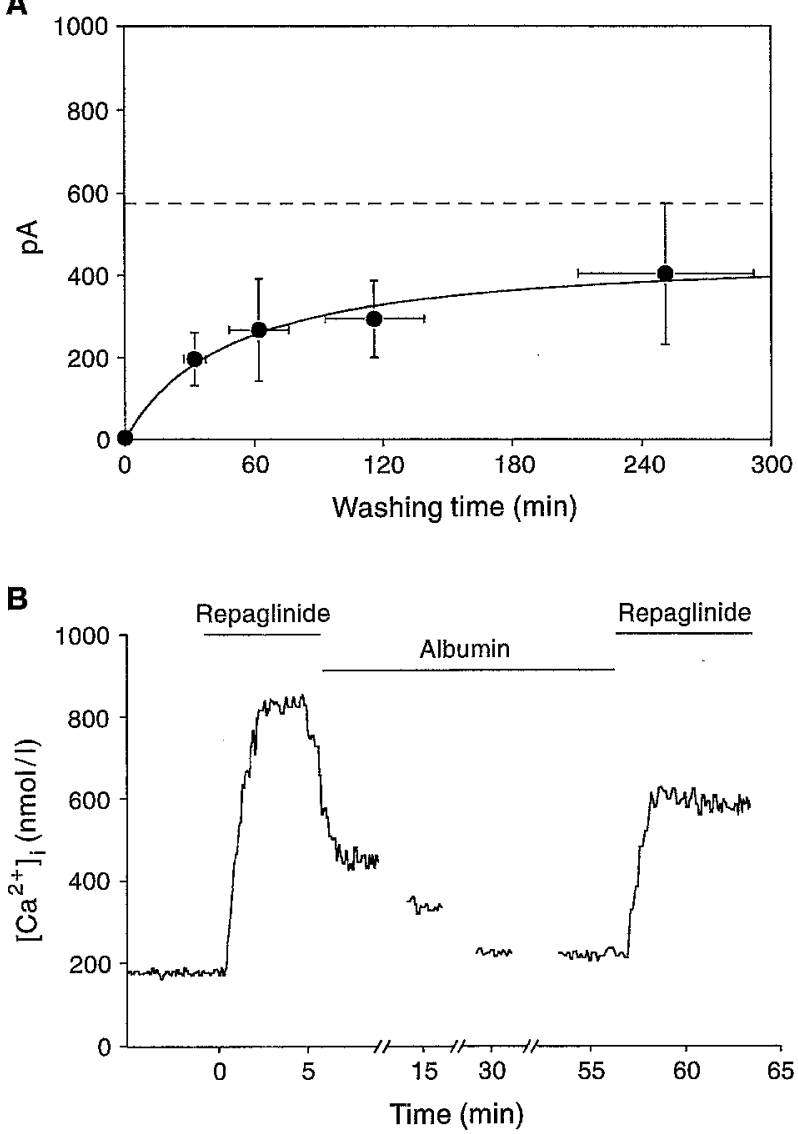

Fig.6(A, B). Reversibility of repaglinide on the ATP-sensitive $\mathrm{K}^{+}$current and $\left[\mathrm{Ca}^{2+}\right]_{\mathrm{i}}$. A Cells were pretreated with 100 $\mathrm{nmol} / 1 \mathrm{repaglinide}$ for $30 \mathrm{~min}$ and then washed for variable periods of time in drug-free medium before a whole-cell experiment was performed. The ordinate shows the maximal whole-cell current in $\mathrm{pA}$. The solid line was obtained by fitting the data points $(n=51)$ to the equation described in text. The dashed line represents the average maximal whole-cell current in control experiments $(575 \pm 33 \mathrm{pA}, n=54)$. B Ca ${ }^{2+}$ response in a $\beta$ TC3 cell after exposure to a maximally stimulating concentration of repaglinide $(100 \mathrm{nmol} / \mathrm{l})$. The cell was washed with bath solution containing $10 \mathrm{mg} / \mathrm{ml}$ albumin. Subsequent addition of repaglinide $(100 \mathrm{nmol} / \mathrm{l})$ took place after $57 \mathrm{~min}$. The tracing is representative of nine experiments

entry and the capacity of the cell will influence the access of the drug to its binding site. It seems likely that much larger amounts of drug accumulate in the cell than are needed to occupy all of the sulphonylurea receptors [25]. If we assume that internalization and accumulation of repaglinide also occurs, this might explain the kinetics of the onset of closure of the $\mathrm{K}^{+}{ }_{\mathrm{ATP}}$-channels and increase in $\left[\mathrm{Ca}^{2+}\right]_{\mathrm{i}}$ observed in the present study. Thus, with submaximal concentrations, the time course of entry and accumulation of repaglinide and glibenclamide in the cell will influence the onset and time course of channel closure and the subsequent increase in $\left[\mathrm{Ca}^{2+}\right]_{\mathrm{i}}$. However, with maximal concentrations, repaglinide and glibenclamide will accumulate in the cell much more rapid- ly and occupy all binding sites, thereby inducing a more rapid rise in $\left[\mathrm{Ca}^{2+}\right]_{\mathrm{i}}$ subsequent to channel closure. The ability of repaglinide and glibenclamide to accumulate in the cell could also explain the slow reversibility on the ATP-sensitive $\mathrm{K}^{+}$-current and $\left[\mathrm{Ca}^{2+}\right]_{\mathrm{i}}$.

In conclusion, the new non-sulphonylurea-based hypoglycaemic agent repaglinide, a benzoic acid derivate, is equipotent with glibenclamide, a second generation sulphonylurea with respect to inhibition of beta-cell ATP-sensitive $\mathrm{K}^{+}$currents and stimulation of an increase in $\left[\mathrm{Ca}^{2+}\right]_{i}$. The close structural relationship between repaglinide and meglitinide, another hypoglycaemic drug which does not contain the sulphonylurea moiety, supports the observation first made by Zünkler et al. [20] that the the sulphonylurea group is not necessary for inhibiting $\mathrm{K}^{+} \mathrm{ATP}^{-}$ channel activity and thus stimulating insulin secretion from the pancreatic beta-cell. It will be interesting to determine whether the non-sulphonylureas such as repaglinide and meglitinide share all properties of the sulphonylureas or if the sulphonylurea part of the molecules confers some distinct biological action.

Acknowledgements. We are indebted to Ms. L. Petri and Ms. T.M. Olsen for expert technical assistance. This work was supported by the NOVO Foundation and the Carlsberg Foundation (SD). JG was sponsored by the Industrial Research Education (ATV) with support from the Ministry of Industry.

\section{References}

1. Gerich JE (1989) Oral hypoglycaemic agents. N Engl Med 321: 1231-1245

2. Ashcroft SJH (1994) The $\beta$-cell sulphonylurea receptor. Diab Nutr Metab 7: 149-163

3. Ashcroft SJH, Ashcroft FM (1992) The sulphonylurea receptor. Biochem Biophys Acta 1175: 45-59

4. Ashcroft FM, Rorsman P (1989) Electrophysiology of the pancreatic $\beta$-cell. Prog Biophys Molec Biol 54: 87-143

5. Ämmälä C, Bokvist K, Eliasson L, Lindström P, Rorsman P (1993) Tolbutamide stimulates exocytosis by direct interaction with the secretory machinery in $\beta$-cells. Diabetologia 36[Suppl 1]:A60 (Abstract)

6. Pontiroli AE, Calderara A, Pozza G (1994) Secondary failure of oral hypoglycaemic agents: frequency, possible causes, and management. Diabetes Metab Rev 10: 31-43

7. Groop LC (1992) Sulphonylureas in NIDDM. Diabetes Care 15: 737-754

8. Panten U, Schwanstecher M, Schwanstecher C (1992) Pancreatic and extrapancreatic sulphonylurea receptors. Horm Metab Res 24: 549-554

9. Wolffenbuttel BHR, Nijst L, Sels JPJE, Menheere PPCA, Müller PG, Nieuwenhuijzen Kruseman AC (1993) Effects of a new oral hypoglycaemic agent, repaglinide, on metabolic control in sulphonylurea-trated patients with NIDDM. Eur J Clin Pharmacol 45: 113-116

10. Frøkjær-Jensen J, Kofod H, Godtfredsen SE (1992) Mechanism of action of AG-EE $623 \mathrm{ZW}$, a novel insulinotropic agent. Diabetologia 35:[Suppl 1]A116 (Abstract) 
11. Høiris Nielsen J, Linde S, Weilinder BS, Billestrup N, Madsen OD (1989) Growth hormone is a growth factor for the differentiated pancreatic $\beta$-cell. Mol Endocrinol 3: 165-173

12. Efrat S, Linde S, Kofod H et al. (1988) Beta-cell lines derived from transgenic mice expressing a hybrid insulin gene-oncogene. Proc Natl Acad Sci USA 85: 9037-9041

13. Trube G, Rorsman P, Ohno-Shosaka T (1986) Opposite effects of tolbutamide and diazoxide on the ATP-dependent $\mathrm{K}^{+}$channel in mouse pancreatic $\beta$-cells. Pflügers Arch 407: 493-499

14. Rorsman P, Trube G (1986) Calcium and delayed potassium currents in mouse pancreatic $\beta$-cells under voltageclamp conditions. J Physiol 374: 531-550

15. Findlay I, Dunne MJ, Petersen OH (1985) ATP-sensitive inward rectifier and voltage- and calcium-activated $\mathrm{K}^{+}$ channels in cultured pancreatic islet cells. J Membr Biol. 88: $165-172$

16. Grynkiewicz G, Poenie M, Tsien TR (1985) A new generation of $\mathrm{Ca}^{2+}$ indicators with greatly improved fluorescence properties. J Biol Chem 260: 3440-3450

17. Cook DL, Hales CN (1984) Intracellular ATP directly blocks $\mathrm{K}^{+}$channels in pancreatic B-cells. Nature 311: 271-273

18. Ashcroft FM (1988) Adenosine 5'-triphosphate-sensitive potassium channels. Ann Rev Neurosci 11: 97-118

19. Sturgess NC, Kozlowski RZ, Carrington CA, Hales CN, Ashford MLJ (1988) Effects of sulphonylureas and diazox- ide on insulin secretion and nucleotide-sensitive channels in an insulin-secreting cell line. Br J Pharmacol 85: 83-94

20. Zünkler BJ, Lenzen S, Männer K, Panten U, Trube G (1988) Concentration-dependent effects of tolbutamide, meglitinide, glipizide, glibenclamide and diazoxide on ATP-regulated $\mathrm{K}^{+}$currents in pancreatic B-cells. Naunyn Schmiedeberg's Arch Pharm 337: 225-230

21. Panten U, Burgfeld J, Goerke F et al. (1989) Control of insulin secretion by sulphonylureas, meglitinide and diazoxide in relation to their binding to the sulphonylurea receptor in pancreatic islets. Biochem Pharm 38: 1217-1229

22. Schmid-Antomarchi H, Weille J, Fosset M, Lazdunski M (1987) The antidiabetic sulphonylurea glibenclamide is a potent blocker of the ATP-modulated $\mathrm{K}^{+}$channel in insulin secreting cells. Biochem Biophys Res Commun 146: $21-25$

23. Zünkler BJ, Trube G, Panten U (1989) How do sulfonylureas approach their receptor in the B-cell plasma membrane? Naunyn-Schmiedebergs's Arch Pharmacol 340: 328-332

24. Carpentier JL, Sawano F, Ravazzola M, Malaisse WJ (1986) Internalization of ${ }^{3} \mathrm{H}$-glibenclamide in pancreatic islet cells. Diabetologia 29: 259-261

25. Findlay I (1992) Inhibition of ATP-sensitive $\mathrm{K}^{+}$channels in cardiac muscle by the sulphonylurea drug glibenclamide. J Pharmacol Exp Ther 261: 540-545 